\title{
Knowledge sharing between research and development: survey results and their implications for the Algerian agri-food sector
}

Intercambio de conocimientos entre Investigación y Desarrollo: resultados de la encuesta y sus implicaciones para el sector agroalimentario de Argelia

Radia Bernaoul (1), Peter Ohly (2), Mohamed Hassoun (3)

(1) École Nationale Supérieure Vétérinaire (ENSV), Algiers, Algeria, radiabernaoui@yahoo.fr (2) ISKO, Bonn, Germany, peter.ohly@gmx.de (3) École Nationale Supérieure des Sciences de l'Information et des Bibliothèques (ENSSIB), Lyon, France, mohamed.hassoun@enssib.fr

\begin{abstract}
Resumen
La falta de una memoria estructurada y visible que apoye la estrategia argelina de potenciamiento del conocimiento profesional y la investigación agronómica, junto con el fraccionamiento del mapa de las empresas e instituciones de investigación especializadas en el tema dificultan la puesta en valor de la producción científica disponible y de los centros de competencia. Por lo tanto, el propósito de este estudio es pensar en cómo hacer visibles los resultados de la investigación científica argelina para promover la mejora de la producción agrícula y el desarrollo económico. Con el objetivo de conocer mejor las necesidades y requerimientos de dicho sistema, se realizaron dos encuestas entre los investigadores y profesionales de Argelia en 2008 y 2010. Los resultados de los dos estudios recomiendan incrementar los vínculos entre el sector económico y la investigación, y establecer un sistema de información con el fin de compartir conocimientos entre los dos sectores. Los resultados de la encuesta nos ayudaron a validar nuestra hipótesis. Argelia tiene una gran necesidad de establecer una plataforma de colaboración creando un sistema nacional de información agrícola de alto valor añadido. En el futuro, se propone que este proyecto incluya la perspectiva de cooperación con el Magreb, con el fin de crear un sistema de información para la gestión y el intercambio de conocimientos entre estos países.
\end{abstract}

Palabras clave: Gestión del conocimiento. Gestión de la información. Ciencias económicas. Sector agrícola. Desarrollo económico. Transferencia de la investigación. Argelia.

\section{Introduction}

Nowadays the control of information becomes more and more important and thus essential for the competitive advantage for the global knowledge-based economy. B. Cheuk (2002) states more precisely that, all too often, the concept of knowledge management, in companies and governments, has not been related to the control of information, and such a situation has under-

\begin{abstract}
The lack of a structured and visible memory in the Algerian approach for professional knowledge and agronomic research, the partitioning of companies and research institutions make the valorization of the pool of scientific production and the centers of competence quite difficult. So, the purpose of this study is to think about how to make visible the results of the Algerian scientific research focused on improvements in production and economic development. With the aim to examine in this task the necessity and requirements of an information management system two surveys were conducted among Algerian researchers and professionals in 2008 and 2010. The results of the two surveys that recommend links between the economic and research sector suggest an establishment of an information system in order to share knowledge between the two sectors. The results of the survey helped us to validate our hypothesis. Algeria has a great need to realize the project of establishing a collaborative platform of a national agricultural information system of high added value. In the future, we propose that this project must include the perspective of cooperation with the Maghreb, in order to create an information system for managing and sharing of knowledge between these countries.
\end{abstract}

Keywords: Knowledge management. Information management. Economics. Agricultural sector. Economic development. Research transference. Algeria.

mined the competitiveness of the companies. For UNESCO, to stimulate economic growth, it is necessary to use information to develop knowledge to take the leadership and to create new products or new practices (UNESCO, 2008). According to the Alexandria Proclamation, adopted in November 2005 the control of the information can be defined as a deterrent "to allow people in all acts of their life to research, to evaluate, to use and to create the information for per- 
sonal, social, professional, and educational goals" (cf. Horton jr, 2007). This is confirmed by P. Arnon et al (1997):

Humanity has produced over the past thirty decades more information than in two thousand years of history, and such an amount of information doubles every four years. The way to filter the information is extremely important.

In this study the agricultural sector of Algeria is of special interest. Only if the results of agricultural research are translated into innovations and are creating new processes for agricultural businesses then an improvement and increase in production can take place and become a support for the country's sustainable development. According to L. Temri et al. (2009, p. 103) "Sustainable development is a relatively old concept in the political field, but it is recent in the field of business management." In agri-food industry, this is an important topic for international institutions, such as FAO and UNEP. In this sense, many debates took place to evolve the food system, including the enterprises, with respect of better consideration of sustainable development". (Temri et al. 2009, p. 104)

In Algeria, decision-makers, scientists, and development actors do not have information sources designed for decision-making. When technological advances and higher value-added activities are concerned, a dysfunction encumbers the Algerian companies and the Algerian research institutions, due to the absence of knowledge management and a lack of valorization and ensuring to foster the sharing of knowledge. The lack of a structured and visible memory in the Algerian approach for professional knowledge and agronomic research, the partitioning of companies and research institutions and technical agencies, and the fragmentation of the scientific output, make the valorization of the pool of scientific production and the centers of competence quite difficult. Research only becomes productive if it is linked to the organization of the society and its economic and social development. However, how can the accurate tools be set up, to meet this need of synergy developing between the different levels of activity of the Algerian agricultural sector?

A huge work is needed to make visible the results of the Algerian scientific research focused on improvements in production and economic development. Nationally, only the establishment of efficient operational mechanisms can ensure the transfer and exploitation of research results so that they can be a source of innovation for the agricultural and industrial sector. Exactly this is the purpose of this research by measuring the knowledge management of the players of the
Algerian agricultural sector by two main surveys. The one is addressed to professionals to analyze their information practices and to examine how the intellectual capital is transferred to companies. And the other one is addressed to researchers to understand their knowledge sharing culture to be able to offer an observation system as an intelligence and development tool for the agricultural sector stakeholders (researchers and producers).

To answer to such a question means to offer an information system which networks all these links between those involved in Research and Development. One of the challenges of such a project is the diversity of its actors and the complexity of the issues at stake that makes the computerization of information modes impossible. In the agricultural sector this is characterized by the rapid shift from a traditional and small-scale activity, which is labour-intensive, to a sector of the world economy in which technology and information play an essential role and where the access to the modern information and communication tools has become a necessity for farmers all around the world, particularly those in developing countries (Bayo, 2004).

Thus, the application of research findings will allow to introduce new products to the market, to center around strategic areas of research, and to define a policy of alliance with socioeconomic actors. Moreover, according to the OECD, knowledge is considered an asset. It may therefore appear both as an input (competence) and as an output (innovation) in the production process. Under certain conditions, it is comparable to a private property that can be bought or sold on the market as a commodity (CERI 2003, p. 12).

In Algeria, since the enhancement of the level of inclusiveness of the national economy into the world economy, by the development of exportoriented projects, the agricultural sector tries to improve its production. The agricultural sector accounts for around $12 \%$ of the total GDP of Algeria. In this regard, it must be borne in mind that Algeria is a country which is still far from being food self-sufficient. Algeria is indeed based on food imports, up to $75 \%$, to meet all its food needs. Furthermore, the grain industry has still to deal with problems of inefficiency and technological obsolescence. Algeria, with a total country population of 32.85 million people, has to import huge volumes of wheat, to satisfy the domestic demand (International Olive Council, 2007). But in terms of higher education and scientific research, we do see that there is a significant intellectual capital. Algeria has a network of 77 higher education institutions, covering 41 wilayas (out of 48 ), comprising 36 uni- 
versities, including one for continuing education, 15 university centers, 16 specialized schools and institutes, and 5 teacher training colleges. In addition, such a sector includes 19 universitybased centers and 640 university research laboratories. Algeria also intends to mobilize up to 28000 teacher-researchers and 4500 permanent researchers.

However, is such a capital focused on economy, in other words, the concerned companies? Do these companies harness advances in science? Is there any synergy between research and development of agri-food products? Are the results of agronomic research applied by the agri-food businesses? Is Economy nourished by Science?

The research sector is linked to the concept of value-added knowledge for the development of the country. H. Bouchet $(2005$, p. 9) states that

[...] the knowledge economy revolves individual knowledge in networks in order to see that the collective production exceeds the sum of the parts. Basic and applied research converge, translated into innovation processes and products intended for uses, which themselves are in perpetual revisions to satisfy the needs of any kind.

The research is creating innovation with the aim to create new products and to develop the most efficient production methods. This act brings together two productive knowledges, the socalled "individual and collective", which should be exploited according to the priorities of the company, on the basis of a pre-defined policy. In this perspective, in 2000, on the European Economic and Social Summit in Lisbon, the EU has set a new strategic goal for the next decade for the improvement of economic development: "Becoming the economy of the most competitive and dynamic, capable of sustainable economic growth." (Libération, 2015). To act against these backdrops the creation of an information management system of the knowledge gained by the agronomic Algerian research has been considered.

\section{Methodology}

As mentioned above, for the setting of a collaborative platform, we carried out two structured surveys among Algerian researchers, resp. teacher-researchers, and among professionals (managers and supervisors) concerning the knowledge management measures in companies, and the assessment of the scientific production of researchers and the types of partnership projects. Finally, is there any mutuality between the two sectors (scientific research and economic development)?
For each survey an exploratory phase was conducted, followed by unstructured interviews and then the main questionnaire survey. An administrative letter was respectively sent also to the concerned research institutions and companies to allow the completion of this survey of researchers and professionals. To explore the field of our study first non-directive, face-to-face interviews with 10 representatives of each of the two groups were carried out in 2008. As for the researcher group these were school directors, deputy directors of research laboratories and heads of three research institutions (the National School Veterinary, the National Superior School of Agronomy and the National Institute of Agronomic Research 'Algeria). As for the professionals these were 10 officials (Directors-General, Directors, Assistant Directors, Heads of Service) affiliated with two companies (Groupe Cevital "Subsidiary food" and New canning Algeria Rouiba "Juice"). For each institution the directors helped us to select 12 researchers, according to their degree assuming that they are more active in scientific production then. This selection differs from that of the exploratory talks. In the food companies we undertook in 2010 the pre-survey with 15 probands (executives, engineers and sales engineers) specifically focused on three main companies, the Cevital Group "Subsidiary food", SIM Group, and Bellat Group.

The feedback from the pre-test has been very effective in gathering personal and subjective opinions and comments. This allowed us to verify the relevance, the understanding of the questions, and to adjust the final two questionnaires (for companies and research institutions). After this pre-test we interviewed different respondents (professionals and researchers) with respect to the perception they had of the questionnaire (length, clarity of questions, difficulty to answer certain questions, etc.).

The first survey was conducted in 26 agricultural research institutes. This survey included researchers specialized in agricultural, veterinary, and biological sciences. It is also aimed at assessing their informational needs to propose an information system focused on the agronomic research, for the sharing and the management of the knowledge arising from the agronomic research. A total of 500 questionnaires was also distributed. Data-collection took over 5 months (from February to September 2008). We received 345 responses, which represents a $69 \%$ response rate. The second survey was much more limited in scope. It was restricted to 20 Algerian agrifood businesses, chosen for their field practices. We interviewed 305 agribusiness professionals to measure knowledge management and the 
transfer level of research outcomes to agri-food businesses. A total of 500 questionaries was distributed. Data-collection took over 7 months (from June to December 2010). As we received 305 responses this represents a $61 \%$ response rate. It is important to note that in this paper we just present partial results of the entire study.

As program for computation and survey processing we used the Sphinx Plus2-V5 for the analysis of responses (frequencies and crosstabulations, see Ganassali, 2009).

\section{Results of the survey on the Algerian scientists}

\subsection{Identification of the target population: Researchers}

Before focusing on the behaviors and practices of such a target population, it is imperative to identify and distinguish its main features. Our target population undertakes research and/or higher education activities. This includes researchers, teacher-researchers and research engineers. The analysis of our survey data shows that $39 \%$ of the researchers are not younger than 36 and not older than 45 . So the target population mostly is a young one. We also see that an enormous percentage of the published research, up to $95 \%$, is being carried out by the $36-45$ age groups. So we have, a young and high-leveled population, who contributes to the producing and sharing of knowledge.

\subsection{Scientific and technical production} of researchers

Most of those examined (95\%, according to a respective question) fully engage themselves in an activity which requires an intellectual exertion. Moreover, by this study, we find that researchers mostly focus on research in direct relation with current affairs, such as conference papers, theses, publication of articles in periodicals. They are not that much interested in publishing in peer reviewed scientific specialized books (Figure 1).

These types of scientific production are strongly linked to research careers. As J.-Y. Cause states "Notre carrière dépend de notre production scientifique (Our career depends on our scientific production)" (CRESS, 2009). Thus, it is indispensable also for Algerian researchers and professors to publish their research results in national and international journals with impact factor and to communicate by scientific events that are increasingly required for advancing their scientific careers.

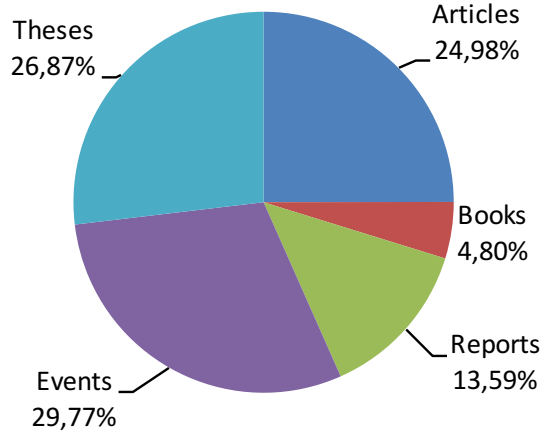

Figure 1. Types of Algerian researchers' scientific publications

Publishing in scientific publications with noteworthy impact factor does determine their career. Accordingly of those claiming to publish in journals with impact factor $70 \%$ are Ph.D. level scientists (Table I).

\begin{tabular}{cccccc}
\hline & Engineer & Master & Ph.D. & Other & Total \\
\hline Yes & $0.8 \%$ & $26.6 \%$ & $70.3 \%$ & $2.3 \%$ & $100 \%$ \\
\hline No & $17.9 \%$ & $70.7 \%$ & $9.8 \%$ & $1.6 \%$ & $100 \%$ \\
\hline No answer & $12.9 \%$ & $67.7 \%$ & $12.9 \%$ & $6.5 \%$ & $100 \%$ \\
\hline Total & $11.3 \%$ & $53.9 \%$ & $32.5 \%$ & $2.3 \%$ & $100 \%$
\end{tabular}

Table I. Impact publications of the Algerian researchers related to the educational qualification

The obtained data reveal the high rate $(88 \%$, according to a respective question) of researchers and teacher-researchers working on research projects. Almost $62.5 \%$ of these projects are institutional-National Evaluation and Programming Research Committee (CNEPRU), National Research Programs (PNR), Research Development National Agency (ANDRU)-, whereas $28 \%$ of these projects are personal, e.g., Ph.D. Thesis (Figure 2).

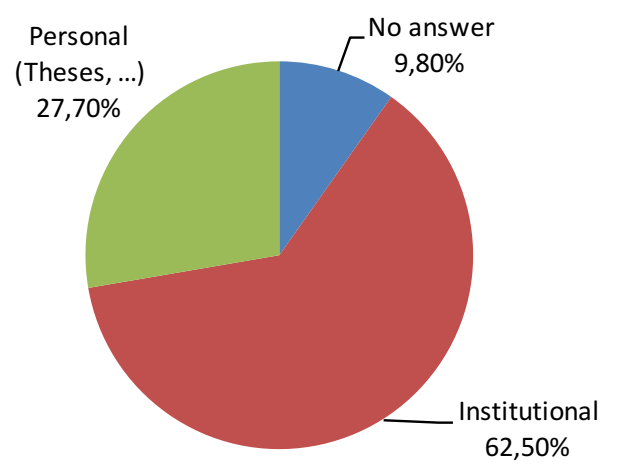

Figure 2. Types of research projects 
A bivariate analysis of the type of research projects and the scientific degree obtained shows that of those having a $\mathrm{PhD}$ are $90 \%$ researchers integrated in institutional projects. $39 \%$ of the Magister graduates are engaged in their dissertation project, of which some are at the same time coming from institutional projects (NRP, CNEPRU) (Table II).

\begin{tabular}{cccccc}
\hline & Engineer & Master & Ph.D. & Other & Total \\
\hline No answer & $28,20 \%$ & $10,70 \%$ & $0,80 \%$ & $22,20 \%$ & $9,80 \%$ \\
\hline Institutional & $61,50 \%$ & $50,00 \%$ & $90,00 \%$ & $44,40 \%$ & $62,40 \%$ \\
\hline Personal & $10,30 \%$ & $38,90 \%$ & $9,20 \%$ & $33,30 \%$ & $27,60 \%$ \\
\hline Other & $0,00 \%$ & $0,40 \%$ & $0,00 \%$ & $0,00 \%$ & $0,20 \%$ \\
\hline Total & $100 \%$ & $100 \%$ & $100 \%$ & $100 \%$ & $100 \%$ \\
\hline
\end{tabular}

Table II. Type of research projects related to the diploma

The high participation of researchers in national calls for proposals does reflect the involvement of the scientific community to take over the socio-economic concerns of the country. $42 \%$ of the ongoing projects are carried out within an academic and official framework (National Evaluation and Programming Research Committee). The remainder divided into the National Research Programs with 24\%, and the Research Development National Agency with 9\%. We also note that $19 \%$ of the researchers are involved in other research programs (Figure 3 )

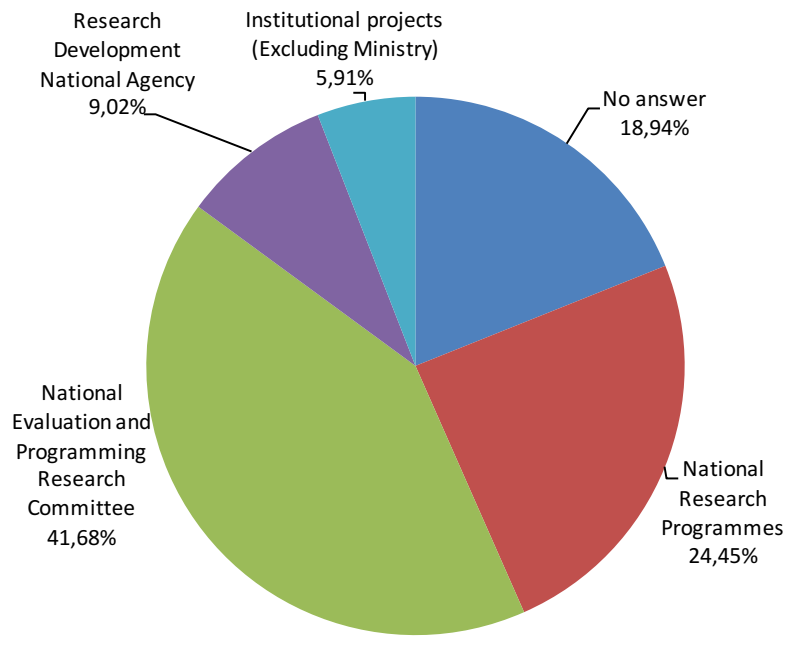

Figure 3. Types of national research programs

Among the questions we were interested in, we also have to notice those which concern the participation of researchers in research projects that revolve around major debates on the global level priorities. A key provision for the participation of researchers in research that concerns major debates on the global level priorities (food security, climate, plant genetic resources...) is the exchange of experiences and cooperation among diverse communities that face similar environmental challenges. Therefore we asked for the potential identification of collective interests in networking for sharing knowledge.

One question concerned the participation of researchers in research projects which are centered on the key global issues (food security, climate, plant genetic resources, etc.). Such issues foster experience and cooperation, shared between various communities that have to face similar environmental difficulties. The distribution of research projects by type of partnership showed that $28 \%$ of the projects are carried out within that kind of cooperation. The amount of $69 \%$ of non-response can be attributed either to the absence of projects carried out within the framework of bilateral and/or multilateral partnerships, or to the fact that the key projects of the Algerian scientists remain too specific and cannot fit into international networks (Figure 4).

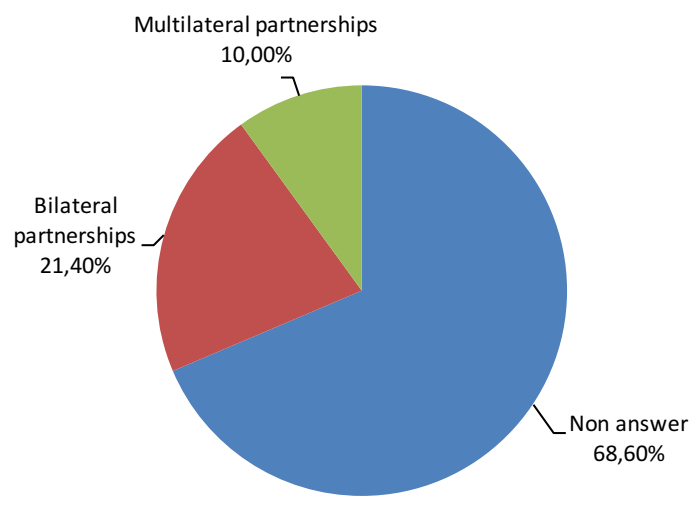

Figure 4. Distribution of the projects by type of cooperation

What concerns the international projects, they are carried out within the framework of bilateral cooperation $(21 \%)$. These co-operations particularly concern France. It is also important to mention the projects in partnership with Morocco, Tunisia, Spain, and Italy. Apparently there is a major problem of transfer of scientific and technical knowledge among Algerian scientists who may be able to benefit from programs such as those of the Food and Agricultural Organization and International Atomic Energy Agency which strongly provide assistance in using the nuclear technologies and related biotechnologies, to 
develop improved strategies to guarantee sustainable food security (AIEA, 2013).

For the time being, good neighborly bilateral agreements on technological and scientific cooperation remain very restricted and only apply to certain Mediterranean countries which are considered as preferred partners. It invalidates the contribution to the international research efforts to respond to agronomic, veterinary, and biological global research challenges.

Also, as a main result we can find that projects are mostly institutional. Doctoral theses projects are largely dependent from the programs of the National Commission for assessing university research projects (CNEPRU) with a slight bilateral partnership orientation. In contrary the national research programs (NRPs) are somewhat more in favor of multilateral collaboration.

In general, the data obtained reveal a vital need to create an appropriate framework for knowledge sharing as collective intelligence that addresses to the existing constraints in Algeria, what means the inadequacy of its agricultural production. This country needs to use its search results as a source of innovation and potency in its current plan to reduce its food bill. However, it lacks tools that promote capitalization and enhancement of its scientific production. In this sense, we will have a look to the project of the National Agricultural Research Observatory in the following chapter.

\section{Results of the survey conducted among the Algerian professionals}

\subsection{Identification of the target population:} professionals

The target population is made of senior managers, engineers, sales engineers, supervisors, whose needs in terms of information and sharing of knowledge are crucial. Concerning the distribution of the targeted population by age group, the survey results show that the targeted population in all the business structures does remain quite young. We note that almost $64 \%$ of the professionals examined are under 40 and that a large majority $(65 \%)$ has a university degree. At first sight, having an academic qualification is the formal criterion for recruitment of staff in companies, if we reasonably apply to our society the notion of "age of knowledge management".

\subsection{Knowledge and informational data among professionals}

The analysis of the data reveals that the majority of the interviewees $(98 \%)$ had a good knowled- ge of the different kinds of information available in their business environment. The primary information access for professionals predominantly remain first and foremost (up to $44 \%$ ) text data (academic journal articles, patents, activity reports, assessments, technical notes, etc.). We see that $25 \%$ of the information is available to the professionals by factual data (statistics, surveys, polls, etc.). But, surprisingly, with a rate of $22 \%$ the electronic information access through multimedia is not that known in the different units of the companies. Many activities which are related to the multimedia are dealing with the computer equipment, professional servers, software, and databases. The geographical information seems to be almost ignored by the professionals in their decision making process $(10 \%)$ (Figure 5). This means that the companies are not that focused on net consolidated sales, value-adding, production, labor cost, or even the investment in other industrial sectors.

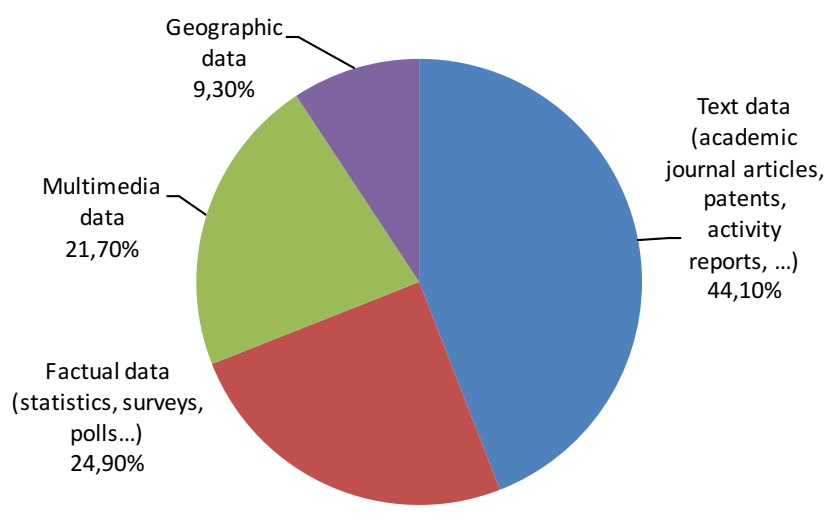

Figure 5. Knowledge of professionals

4.3. Forms of distributing and sharing knowledge

\subsubsection{Circulation of information and knowledge}

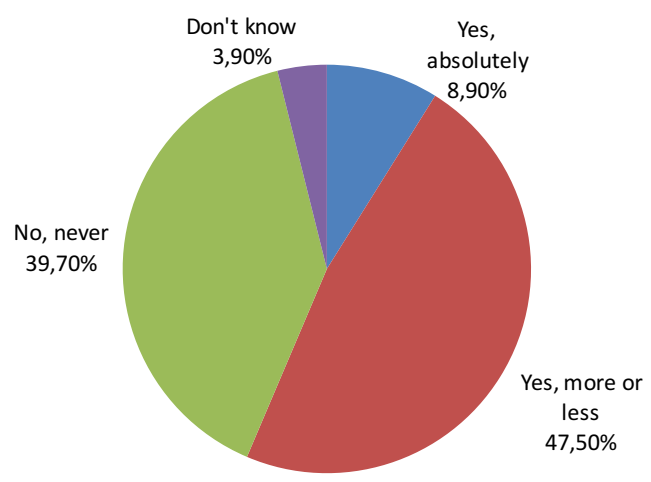

Figure 6. Circulation of information within companies 
$47 \%$ of the professionals believe that the information flows in a more or less satisfactory manner and $40 \%$ believe that the information does not properly flow between the ones who launch it and the ones who receive it. On the contrary, $9 \%$ of the professionals seem to be fairly optimistic about how the process of circulation of professional information works (Figure 6).

\subsubsection{Barriers to the flow of information}

What may restrict the proper circulation of knowledge and circulation within companies mostly is the lack of coordination in the international communication $(20 \%)$ and the retention of information (17.5\%). According to those examined, such a situation has to be linked to the problem of professional competition, which exists in most of the companies. As for those hierarchically responsible, they are weakly involved in the internal communication process (14\%) (Figure 7).

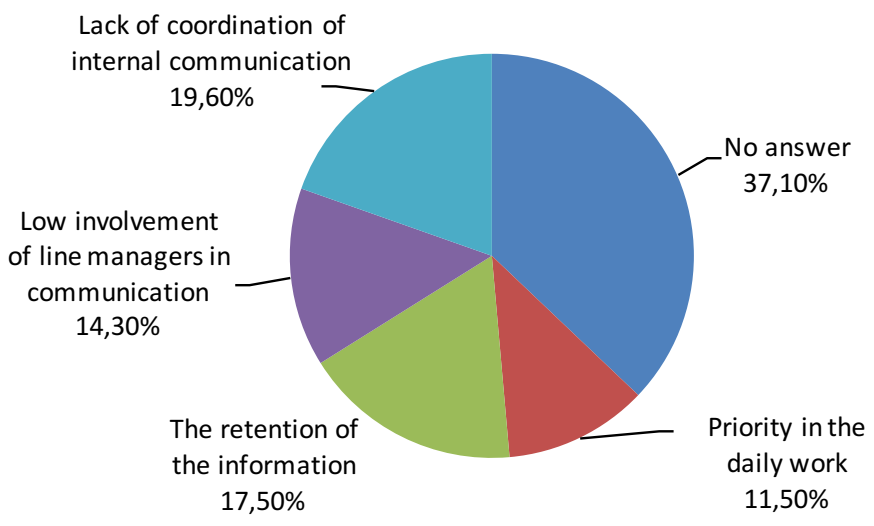

Figure 7. Barriers to information flow

\subsection{Scientific research: A tool for innovation}

In this context, we raise the following issue: «ls research a tool for development?». Answering this fundamental question means to focus on the ones who need development assistance to find out if they really use information as a tool for development.

\subsubsection{Scientific research and development assistance}

It appears that for all the interviewees scientific research is regarded as a tool for development $(99 \%)$. Such a response rate does justify our fundamental question. Most of the respondents are researchers and research laboratories with respective rates of $28 \%$ and $26 \%$. And with a rate of $15 \%$ the research results were carried out within research institutions. On the contrary, the recourse to external expertise from consul- tancy agencies or expert committees, as a tool for development, only represents $10 \%$, respective $11 \%$ (Figure 8 ).

Senior managers stated that expertises are not really developed in Algerian agriculture, especially not in the agri-food business, whereas scientific relationships of research managers are very important in projects that consider the question of financial and economic profitability.

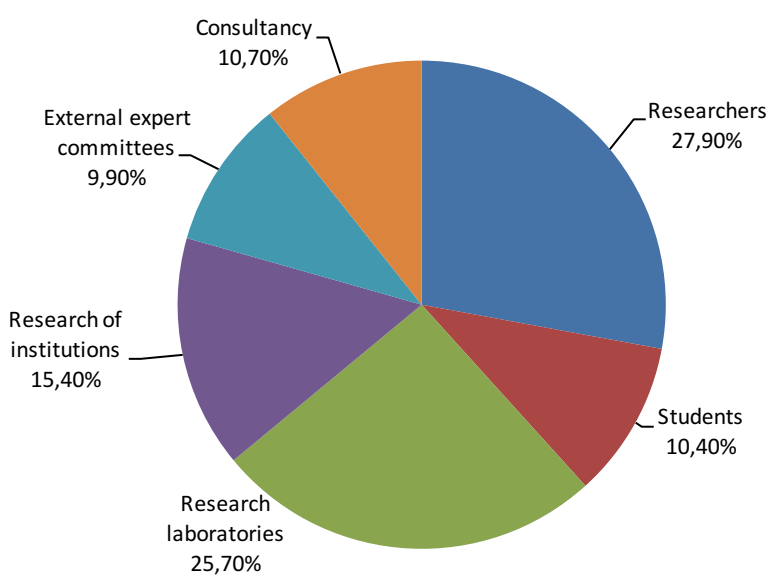

Figure 8. Internal and external research guidance

\subsubsection{Scientific research and innovation: synergy between companies and scientific research}

$44 \%$ of the respondents want to have easier access to research results. There is also a special interest given to technical proceedings $(32 \%)$ (Figure 9$)$. While studies on the impact of expertise and patents in the academic research institutions underline a low level of interest among the researchers $(16 \%$ and $8 \%)$. These results do confirm indeed what was previously stated concerning the ignorance of professionals of that kind of information source under the aspect "collaboration and knowledge sharing".

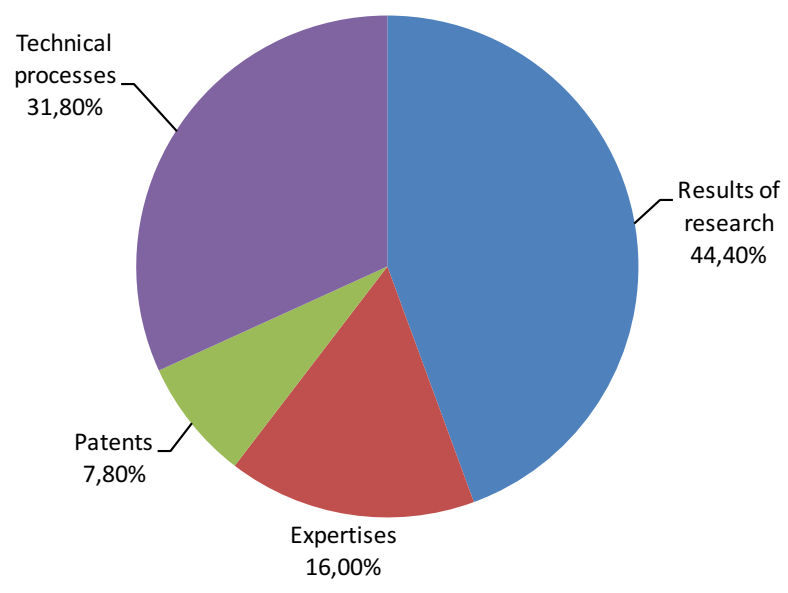

Figure 9. Expectations of research professionals 


\subsubsection{Corporate involvement and support to research activities}

According to a respective question, $77 \%$ of professionals indicate that their companies do not fund innovation research, neither a special expertise in responsibility of the university to find out their real needs. But the transfer of research results (prototypes, standards, patents, etc.) is becoming more and more important in industries. Companies have to get involved in a learning process, thanks to the transmittance of research and production, and a cooperative networking with external partners. In that case, slightly more than half of the professional community (54\%) believes that the company capitalizes the research results from university, whereas $46 \%$ state that research is focused on the needs of the industrial companies (Figure 10). That being said, companies have to support research activities. We suggest that strong linkages have to be created between companies and university.

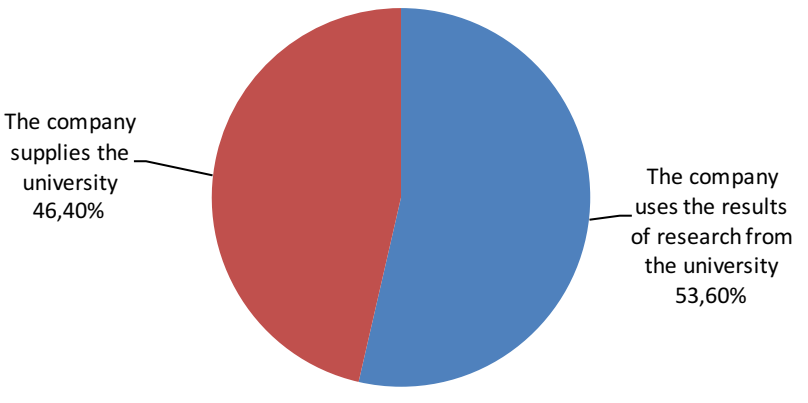

Figure 10. Modalities of synergy between university and companies

The collected data clearly underline the necessity to set up a knowledge management system in the Algerian agri-food businesses. This tool aims to capitalize on knowledge (experience feedbacks, skills management, etc.) to set up exchange spaces (knowledge data bases, document management, collaborative platforms, etc.).

In summary, we can say that scientific research and industrial innovation nourishes economic activity and vice versa. To achieve this mutuality and coherence between different sectors (scientific and economic), Algeria must prepare a development plan for fostering alliances between the research directions and the economic production sector.

As a result, our findings and conclusions are in perfect agreement with the request that was made in 2011 by the Algerian General Directora- te for Scientific Research and Technological Development (MESRS) who has set as goal the evaluation of research, to make it more visible; while establishing links between scientific research and technological development in order to connect universities with the socio-economic sector. In this perspective the government (Le Président, 2010) demands: "we cannot miss any effort to promote scientific research". This says that the professional community, the sharing and synergy practices are virtualcarriers of innovation; especially if they are going to be built around common interests.

These results confirm that there should be an opening of the professionals to the world and an inclusion into socio-scientific networks which contribute to improve the production and performance of the Algerian food company. This pooling and these exchanges are now a real support for good quality of the production of the food industry.

\section{Conclusions}

This study does confirm the need for an information and knowledge sharing system which will facilitate the collaborations between researchers and professionals to pool knowledge and knowhow. To that end, the creation of a collaborative space should be considered. Such a space will provide an accurate visibility of information and knowledge to strengthen the institutions by setting up networks of actors. The point is to establish closer links with people who share a similar interest (scientists, professionals, political leaders, etc.).

The survey project itself approves as a tool to support reflections and decisions for the development of a rational national strategy for agricultural research. It will facilitate the implementation of the research policy and enable the evaluation of results with respect to innovations, publications, partnership agreements and transfer of skills. It also aims to create synergies among national research programs, and between the research sector and the economy (Issolah, 2010).

On this basis we can say that the competitiveness clusters and the poles of excellence are ways to build networks of skills, knowledge, as wells as means, to foster the innovation and the creation of added value in a knowledge economy which is currently being built and globalized. This sharing between the two poles enables a possible pooling of business leaders, universities, knowledge institutions, research laboratories in a region. According to $\mathrm{A}$. Bencharif and $\mathrm{K}$. Belkahia (2009), to cope with new challenges 
posed by the coordination of economic operators and knowledge institutions, it is vital to encourage measures that allow the acquisition and the diffusion of knowledge, through

[...] a partnership between research and development organizations and the world of production, with the support of public authorities, mostly local ones, to improve the competitiveness of regions and of the companies involved in such a process.

This model is based on support tools for collaborative work, called "collaborative platform". By it we propose an information system model which is capable to manage the intellectual capital of the Algerian agricultural sector and to create value from intellectual assets.

Information and communication technology and especially such platforms enable to exploit collaborative processes that underlie collective innovation (Isckia, 2011, p. 22). This leads to the creation of competitive advantages. In this context, platforms are means that provide access to resources and facilitate interaction between partners in a collective innovation process, which can be more or less open. These platforms are devices that are intended to facilitate interaction between two or more groups of interdependent actors (Isckia, 2011, p. 23).

This is as well the position of Evans: "Those software platforms are at the heart of "economies" or "ecosystems", that consist of mutually dependent communities of businesses and consumers who have symbiotic relationship with the platform" (2008, p. 23). The collaborative platform we offer is going to stir and contribute to national considerations. In fact, Algeria has also started to think about an information system that aims to break down the barriers between different actors of the agricultural sector and to transfer knowledge to enable research as a tool for development.

This project involves the production of indicators in order to plan research and pooling of all players in this sector (research, training, production). In light of our results, we confirm a decisive need for sharing and pooling of all stakeholders to create a knowledge society and economy. In the future, this project should include the perspective of cooperation with other countries, e.g. the establishment of a Maghreb information system for managing and sharing of knowledge.

\section{References}

AIEA (2013). Activites de la division mixte FAO/AIEA des techniques nucleaires dans l'alimentation et l'agriculture en rapport avec les traveaux sur le codex. hftp://hftp.fao.org/codex/Meetings/cac/cac36/if36 07f.pdf (2015-5-31)
Arnon, P. et al. (1997). L'info, nerf de la guerre. Dossier Intelligence Economique. // Le Monde Informatique. 731 (1997-5-8).

Bayo, L. (2004). Système d'informations régionales sur les filières vivrières adapté aux Organisations professionnelles en Guinée. Montpellier: CIHEAM-IAMM. Mémoire (Master of Science). 2004. http://www.iamm.fr/ressource s/opac_css/index.php?|vl=author_see\&id=1220 (2015-531)/

Bencharif, A.; Belkahia K. (2009). Technopoles agroalimentaires et Agropoles dans les pays du Maghreb. Opportunités, spécificités, défis. // Abis S. et al. (eds.). Perspectives des politiques agricoles en Afrique du Nord (Options méditerranéennes série $B$, vol. 64). Paris : CIHEAM, 2009. 233-238.

Bouchet $H$. (2005). La société de la connaissance dans le cadre de la stratégie de Lisbonne. Conseil économique et social. // Journal officiel de la République française, avis et rapports du Conseil économique et social. http://www.lecese.fr/sites/default/files/pdf/Avis/2005/200 5_17\%20_hubert_bouchet.pdf (2015-9-9) 2005.

CERI - Centre pour la recherche et l'innovation dans l'enseignement(2003). Organisation de coopération et de développement économique. Société du savoir et gestion des connaissances. Paris, 2003.

Cheuk, B.,2002. Information Literacy in the Workplace Context: Issues, Best Practices and Challenges. White paper for use at the Information Literacy Meeting of Experts, Prague, the Czech Republic. Cited in UNESCO, 2008.

CRESS - Centre de recherches et d'études en sciences sociales(2009). UMB. Le malaise des enseignantschercheurs. // Le malaise des enseignants-chercheurs. http://savoirs.nameo.fr/docs/chercheurs_entre_liberte_et rentabilite.pdf (2009-11-2)

Evans, D.-S., Schmalensee, R. (2007). The Industrial Organization of Markets with Two- Sided Platforms. // Competition Policy International. $3: 1,151-179$. Cited in: Isckia Thierry, 2011. Ecosystèmes d'affaires, stratégies de plateforme et innovation ouverte: vers une approche intégrée de la dynamique d'innovation. // Management \& Avenir. 46, 2011, 157-176 . DOI: 10.3917/mav.046.0157 (2015-9-10).

Ganassali, S. (2009). Les enquêtes par questionnaire avec Sphinx. Paris, Pearson Education, 2009.

Horton jr., F. (2007). Introduction à la maîtrise de l'information. Paris: UNESCO, 2007. http://unesdoc.unes co.org/images/0015/001570/157020f.pdf (2015-6-10)

International Olive Council (2007). Indicateurs macroéconomiques et agricoles. Dossier Algérie. E.108/Doc., 4. Mise à jour 32 :02. 1 .

Isckia, T. (2011). Ecosystèmes d'affaires, stratégies de plateforme et innovation ouverte : vers une approche intégrée de la dynamique d'innovation. // Management \& Avenir. 46 (2011) 157-176 . http://www.cairn.info/revuemanagement-et-avenir-2011-6-page-157.htm. (2015-910) DOI : 10.3917/mav.046.0157

Issolah, R. (2010). The Observatory of Algerian Agricultural Research. An integrated scientific information system as a public policy enabler. // IAALD XIIIth World Congress. Agropolis International. 26-29 April 2010, MontpellierFrance.

Le Président (2010). Le Président de la Republique à propos de La rétribution des chercheurs et le statut du doctorant // El Bahth. Revue de la direction générale de la recherche scientifique et du développement technologique, 3 (2010) 20. http://www.dgrsdt.dz/admin/news upload/ RevueEIBahth3.pdf (2015-5-31).

Libération (2015). Croissance économique, Dynamique, Durable. http://resume.liberation.fr/croissance-economi que-dyna mique-durable.html (2015-7-7). 
Temri, L. et al. (2009). Partages des bonnes pratiques de développment durable: le cas des PME agroalimentaires du Languedoc-Roussillon. // Cahiers d'économie de l'innovation, 29 (2009) 103- 125.

UNESCO (2008). Vers des indicateurs de la maîtrise de l'information. Paris: UNESCO, 2008. http://www.uis.unes
co.org/Library/Documents/wp08 infolit-fre.pdf

$(2015-5-$ 31).

Enviado: 2015-05-08. Segunda versión: 2016-03-08 Aceptado: 2016-05-19 